\title{
The MIF-Sulfur record suggests the oxygenated atmosphere and sulfate- rich oceans through geologic history
}

\author{
HiROSHI OHMOTO ${ }^{1}$ \\ ${ }^{1}$ Dept. of Geosciences, The Pennsylvania State University, \\ University Park, PA 16803 USA
}

The presence of MIF-S in Archean rocks, and the scarcity of MIF-S in younger rocks, have been accepted by most geoscientists as unequivocal evidence for an anoxic Archean atmosphere and the G.O.E. at $2.5 \mathrm{Ga}$. This theory has been based on an (unspoken) assumption that the MIF-S was created near the Earth surface by the UV photochemical reactions (UV-PCR) of volcanic $\mathrm{SO}_{2}$. The UV-PCR of $\mathrm{SO}_{2}$ would be largely prevented if the $\mathrm{P}_{\mathrm{O} 2}$ were $>10^{-5} \mathrm{PAL}$ in the troposphere. Here I suggest that the MIF-S in Archean sedimentary rocks were generated by: (1) the UV-PCR in the stratosphere $(>\sim 15 \mathrm{~km}$ above S.L.) over an oxygenated troposphere of the $\mathrm{SO}_{2}$ emitted by Plinian-type explosive volcanic eruptions and/or (2) high $\mathrm{T}$ (> $\sim 150^{\circ} \mathrm{C}$ ) heterogenous reactions between $\mathrm{SO}_{4}{ }^{2-}$ and highly-reactive organic matter (solid or liquid) in marine basins where abiotic, cell-free organic matter was abundantly produced by submarine hydrothermal processes. Both processes (atmospheric and oceanic) for MIF-S creation would have been important on early Earth when the Earth was hotter and magmatism was more intensive and extensive on land and in oceans than today. The above suggestions are based partly on the discoveries of: (i) MIF-S in ashes from Mt.

Pinatubo \& Mt. Agung; (ii) the abundance of ash layers in MIF-S-bearing Archean shales; (iii) the experimental generation of MIF-S by UV-PCR of $\mathrm{SO}_{2}$ in $\mathrm{O}_{2}$-rich atmospheres; (iv) the evidence in 2.7 Ga-old Femeteorites of an $\mathrm{O}_{2}$-rich upper atmosphere; and (v) the experimental data on MIF-S generation during thermochemical sulfate reduction by amino acids. 